\title{
Krystyna GOMÓŁKA
}

DOI : $10.14746 / \mathrm{pp} .2019 .24 .4 .5$

Gdańsk University of Technology

ORCID ID: 0000-0002-7046-0729

Izabela BORUCIŃSKA

Gdańsk University of Technology

ORCID ID: 0000-0002-6717-1379

\section{Youth civic participation from the perspective of Polish and Lithuanian institutions as illustrated by project South Baltic Youth Core Group Network}

\begin{abstract}
The aim of the paper was to show youth civic participation in the opinion of employees of institutions operating in 5 Polish municipalities: Dzierzgoń, Elbląg, Gdynia, Iława and Nowe Miasto Lubawskie and the Lithuanian municipality of Teslai. Within the SB YCGN project, a diagnostic survey was conducted using an online survey technique on 118 respondents from 53 Polish institutions and 47 respondents from 10 Lithuanian institutions.. Based on the results of quantitative research, the hypothesis was confirmed: similarities in the level of civic participation of young people, barriers, needs and effective methods of operation in the analysed communes from Poland and Lithuania determine the need to strengthen cross-border cooperation.
\end{abstract}

Key words: youth, civic participation, Poland, Lithuania, SB YCGN project

\section{Introduction}

$\mathrm{C}$ ivic participation or engagement means speaking out and taking an active part in events that concern the citizens of a specific territory, including youth as a group. Civic participation is a type of communication whereby authorities can learn the society's views on many issues and consider them in the decision-making process. It enables citizens to exert influence and control over the decisions of public authorities (Dlugosz, Wygnański, 2005, pp. 11-12). The terms civic participation and civic engagement are often used interchangeably and there are many definitions of these concepts based on different cultural contexts (Rizzini et al, 2009). The issues of civic participation are complex and multidimensional (Teney, Hanquinet, 2012, pp. 1213-1226), thus requiring continuous cross-disciplinary studies in changing circumstances.

The aim of the study is to show the civic participation of young people as viewed by the staff of institutions operating in 5 Polish communes: Dzierzgoń, Elbląg, Gdynia, Iława and Nowe Miasto Lubawskie and the Lithuanian commune of Teslai.

The research hypothesis is as follows: similar levels of youth civic participation, barriers, needs and effective methods of operation in the Polish and Lithuanian communes investigated determine the need to tighten cross-border cooperation in the Baltic Sea region.

To test this hypothesis, the authors formulated the following research questions: 
1) What is the current level of youth civic participation in the partner municipalities from the viewpoint of public institutions and NGOs in Poland and Lithuania?

2) What is the level and scope of youth involvement in the decision-making processes in the partner Polish and Lithuanian communes?

3) What are the barriers to cooperation with young people in the partner Polish and Lithuanian communes?

4) What are the needs and expectations of public institutions and NGOs in respect of increasing youth civic participation in the partner Polish and Lithuanian communes?

5) To what extent does project South Baltic Youth Core Group Network meet the institutional needs for youth civic participation development in the partner countries?

The following research methods were used in this study: comparative, literature, legal and institutional analysis and quantitative studies.

\section{Theoretical background}

The term "youth" refers to a social category of people defined by the age criterion. According to Stefan Baley, it includes individuals between 13 and 20; Mieczysław Kreutz defines youth as the period between 11 and 21 years of age, and Maria Żebrowska - as the period between 12 and 18 years of age (Pater, Pater, 2008, p. 49). In the opinion of Mieczysław Markiewicz, youth includes those between 15 and 29 (Markiewicz, 1964). Various international organisations also use different age ranges. For example, Eurostat and the European Commission classify youth as people aged 15-29 and 13-30, respectively (Youth in Action). Since the definitions of youth vary widely, even in the EU, (GąsiorNiemiec, 2014, p. 9), one might adopt a more general view and assume that it is "the period of human life characterised by the absence of developed cultural awareness, with people in that age group being influenced by various attitudes and orientations and showing the ambition to change the reality, criticism towards adults, dissimilarity of interests and aspirations and frequent lack of moderation in the pursuit of a model of independent life and new means of self-creation" (Chodubski, 2000, pp. 311-315; Pawliczuk, 2000, pp. 311-315).

The importance of young people in modern society is due to two main factors: their future role in society and the protection of human rights. Thus youth civic engagement is a key aspect of the future development of each society and should be shaped by means of effective youth policy (Rystina, Kussainova, 2014, pp. 654-656). Participation of young people in the public life is crucial for social processes. By enhancing the dialogue with youth, the quality and legitimacy of public policies can be improved.

A number of the activities, structures and processes can be identified within the different spheres of participation (Brodie et al., 2009, pp. 4-5):

- in the public sphere (structures within the existing decision-making structures and processes) there are forms such as youth councils, youth parliaments, school councils, youth advisory panels, members and leaders of youth organisations or groups; voting; standing for election or official, organisational or institutional panel or committee and formal consultations;

- in the social sphere (formal or informal structures created outside of formal political or organisational structures) these include civil society organisations; social or 
cultural groups; local services or projects; social movements; grassroots campaigns; housing associations; faith groups; informal networks; identity or interests groups;

- in the individual sphere (individual choices, decisions and interaction with the world) they are: involvement in decisions having a direct effect on individuals (e.g. judicial proceedings); educational and health matters; choices, decisions and behaviour as part of everyday life; personal customs, values or principles; religious beliefs; consumer choices.

The techniques used in the participation process are: public consultations, referenda, civic law-making initiatives, intermediate representative bodies, request for access to public information, public hearing, communication with councillor/mayor, participation in sessions, meetings with residents, civic panels, round tables, petitions, demos, protests, making documents available at public offices, Internet tools: SMS, instant messaging, Skype; online transmissions, as well as quantitative and qualitative studies (Sokalska, 2016, pp. 163-176). Young people can also influence the decisions of the public and non-public entities through commune youth councils (EU Youth Strategy; Maciaszek, 2016, pp. 13, 171-187), school/student governments (Napiontek, 2013, pp. 105-106) or NGOs (Partycypacja organizacji pozarzadowych).

\section{Description of project SB YCGN and quantitative studies}

South Baltic Youth Core Group Network (SB YCGN) is a project financed under the Interreg V-A South Baltic Programme 2014-2020. It aims to intensify cross-border cooperation, resulting in building the potential of local actors working with youth, to solve common youth issues through boosting cross-border cooperation between partner countries and to improve the capacity and competence of local governments and their representatives to engage in civil dialogue with youth. The project consortium was formed by 8 main and 6 associated partners from Poland, Lithuania, Denmark and Sweden. The project is implemented in 5 Workpackages (WPs), for which the individual partners are responsible, as shown in Table 1.

The associated partners are Vimmerby Municipality - Culture and Leisure Department (Sweden); Town and Commune of Dzierzgoń, Municipality of Elblag, Municipality of Gdynia, Municipality of Iława and Municipality of Nowe Miasto Lubawskie - (Poland).

WP 3 includes quantitative and qualitative studies of the representatives of the institutional environment of youth aged 14-24. The studies were designed by the researchers from the Faculty of Management of Gdańsk University of Technology and Klaipeda University $^{1}$ to determine the local needs related to youth civic participation. They will enable comparison of the actual youth participation and the opinions of the officials, NGO activists and teachers in Lithuania, Poland and Sweden, as well as designing activities to increase youth engagement at the local and cross-border levels. The final recommendations will be addressed to a wide audience of stakeholders.

${ }^{1}$ Composition of the research team: prof. dr hab. Krystyna Gomółka, dr Izabela Borucińska (Gdańsk University of Technology), prof. dr Ligita Šimanskienè, prof. dr Rimantas Stašys, prof. dr Rasa Viederytė, dr Jurgita Paužuolienė (Klaipeda University). 
Partners of the South Baltic Youth Core Group Network Project

\begin{tabular}{|c|c|c|c|}
\hline $\begin{array}{c}\text { Partner } \\
\text { No. }\end{array}$ & Partner & Country & Responsibility for WPs \\
\hline 1 & $\begin{array}{l}\text { Association of Polish Communes of Eu- } \\
\text { roregion Baltic (Lead Partner) }\end{array}$ & Poland & $\begin{array}{l}1 \text { (Management and Coordination), } 2 \text { (Com- } \\
\text { munication and Dissemination) }\end{array}$ \\
\hline 2 & Civis Polonus Foundation & Poland & 4 (Expert Support to Local Governments) \\
\hline 3 & $\begin{array}{l}\text { Public Establishment Samogitia Commu- } \\
\text { nity Foundation }\end{array}$ & Lithuania & $\begin{array}{l}5 \text { (Exchange of International Civic Partici- } \\
\text { pation Practises and Experiences) }\end{array}$ \\
\hline 4 & $\begin{array}{l}\text { Telsiai District Municipality Administra- } \\
\text { tion }\end{array}$ & Lithuania & - \\
\hline 5 & Municipality of Køge* & Denmark & - \\
\hline 6 & $\begin{array}{l}\text { Gdańsk University of Technology, Fac- } \\
\text { ulty of Management and Economics }\end{array}$ & Poland & $\begin{array}{l}3 \text { (Building Knowledge and Expertise on } \\
\text { Youth Civic Participation) }\end{array}$ \\
\hline 7 & Klaipeda University & Lithuania & - \\
\hline 8 & $\begin{array}{l}\text { Municipality of Hässleholm - EU office } \\
\text { Skåne Nordost** }\end{array}$ & Sweden & - \\
\hline
\end{tabular}

* Koge Municipality quit the project as of 01.04.2019 due to commune budget cuts.

** Initially, the Vimerby Municipality was a project partner.

Source: Authors' compilation based on SB YCGN data, see also: Launch of Project SB YCGN - South Baltic Youth Core Groups Network, http://eurobalt.org.pl/aktualnosci/450/start-projektu-sb-ycgn--south-balticyouth-core-groups-network.

The aim of the quantitative study was to identify and evaluate the four main issues at the local and cross-border level: youth participation level in solving local/cross-border problems; youth participation in decision-making, key barriers to increasing youth civic participation, needs of public institutions and NGOs in respect of increasing youth civic engagement at local/cross-border level and effective forms and methods of including youth in active public life that are available to public institutions and NGOs. The research employed the diagnostic survey method based on the use of an online electronic questionnaire. The sample population consisted of the staff of institutions dealing with the issues of youth aged 14-24²-240 respondents from 5 Polish communes (Dzierzgon, Elblag, Gdynia, Iława and Nowe Miasto Lubawskie), 1 Lithuanian (Teslai) and 1 Swedish commune (Hassleholm) selected based on expert opinion. The study included public institutions i.e. town halls, Town Councils, Youth Commune Councils, educational institutions (mainly schools), cultural institutions and NGOs in the communes investigated. It covered 159 respondents from 53 institutions in Poland and 47 respondents from 10 institutions in Teslai, to reflect the population of communes and number of local institutions. Descriptive statistics elements were used in data analysis.

\section{Results of investigation}

Of the total of 240 respondents to be surveyed, $66.25 \%^{3}$ of the sample was taken in Poland and $19.58 \%$ in Lithuania. A majority of those surveyed $-59.3 \%$ in Poland and

2 The age criterion was determined based on practices of the EU and SB YCGN partner countries.

341 questionnaires were rejected because of missing answers in excess of the statistical error of $3 \%$. 118 out of 159 questionnaires $(74,21 \%)$ were accepted for analysis. 
$51 \%$ in Lithuania - worked with youth aged $14-17$. There were more women among the respondents (58.5\%) in Poland but more men (51\%) in Lithuania to reflect the local town population structure. A characteristics of the sample part taken in Poland and Lithuania is presented in Table 2 .

Table 2

Sample structure representing partners from Poland and Lithuania (frequency, $\%$ of responses)

\begin{tabular}{|l|c|c|c|c|c|}
\hline \multicolumn{1}{|c|}{ Partner } & $\begin{array}{c}\text { People working } \\
\text { with youth aged } \\
\mathbf{1 4 - 1 7}\end{array}$ & $\begin{array}{c}\text { People working } \\
\text { with youth aged } \\
\mathbf{1 8 - 2 4}\end{array}$ & Female & Male & $\begin{array}{c}\boldsymbol{\Sigma}(\mathbf{\%}) \\
\text { answers }\end{array}$ \\
\hline Dzierzgoń & $6(5.1)$ & $4(3.4)$ & $6(5.1)$ & $4(3.4)$ & $10(8.5)$ \\
\hline Elbląg & $15(12.7)$ & $16(13.5)$ & $19(16.1)$ & $12(10.1)$ & $31(26.3)$ \\
\hline Gdynia & $25(21.2)$ & $20(17)$ & $25(21.2)$ & $20(17)$ & $45(38.1)$ \\
\hline Iława & $7(5.9)$ & $3(2.5)$ & $8(6.7)$ & $2(1.7)$ & $10(8.5)$ \\
\hline Nowe Miasto Lubawskie & $17(14.4)$ & $5(4.2)$ & $11(9.3)$ & $11(9.3)$ & $22(18.6)$ \\
\hline Polish communes $\Sigma(\%)$ & $70(59.3)$ & $48(40.7)$ & $69(58.5)$ & $49(41.5)$ & $118(100)$ \\
\hline Telsiai & $24(51.06)$ & $23(48.93)$ & $23(48.93)$ & $24(51.06)$ & $47(100)$ \\
\hline
\end{tabular}

Source: Authors' compilation based on SB YCGN Project data.

The structure of the institutions surveyed in Poland and Lithuania was similar, with a majority of respondents representing schools $(42.7 \%$ in Poland and $35.9 \%$ in Lithuania - mainly teachers). The second largest group were NGO workers $-10.9 \%$ of the sample in Poland and 32.8\% in Lithuania. The next group represented staff of local government institutions $-10.9 \%$ of respondents in both countries, followed by town hall employees $-6.4 \%$ in Poland and $9.4 \%$ in Lithuania. Employees of culture centres accounted for $3.6 \%$ in Poland and $3.1 \%$ in Lithuania, whereas social assistance workers $-1.8 \%$, and in $3.1 \%$, respectively. The remaining respondents represented other public institutions.

The first survey question was about the frequency of attitudes of young people concerning their influence on the immediate environment (school, neighbourhood, commune, local environment. A majority of respondents reported that youth were often eager to have an influence on such matters (27.6 pp more in Lithuania than in Poland) whereas that attitude was observed very frequently by $26 \mathrm{pp}$ more respondents in Poland. ${ }^{4} \mathrm{~A}$ majority of persons surveyed in both countries said that young people are often willing to engage in cooperation for the immediate environment - $13.9 \mathrm{pp}$ more Lithuanian than Polish respondents. 2.2 pp more Poles than Lithuanians had no clear view on that matter. Evaluation of the statement that youth often expect adults to assist them in solving their problems gave similar results. $7 \mathrm{pp}$ more Polish than Lithuanian respondents expressed that view. The second most popular choice among Polish respondents was "very often." In Lithuania the same percentage of responders chose the options "very often" and "rarely." The distribution of the variable is shown in Table 3.

${ }^{4}$ A majority of respondents in Gdynia (16.5\%), Nowe Miasto Lubawskie (7.6\%) and Dzierzgoń (4.2\%) chose the option "very often." The option "often" was chosen by more respondents in Elblag $(8.5 \%)$ than Iława (5\%). In Dzierzgon both options were indicated by the same number of people $(4.2 \%)$. 
$\frac{0}{0}$

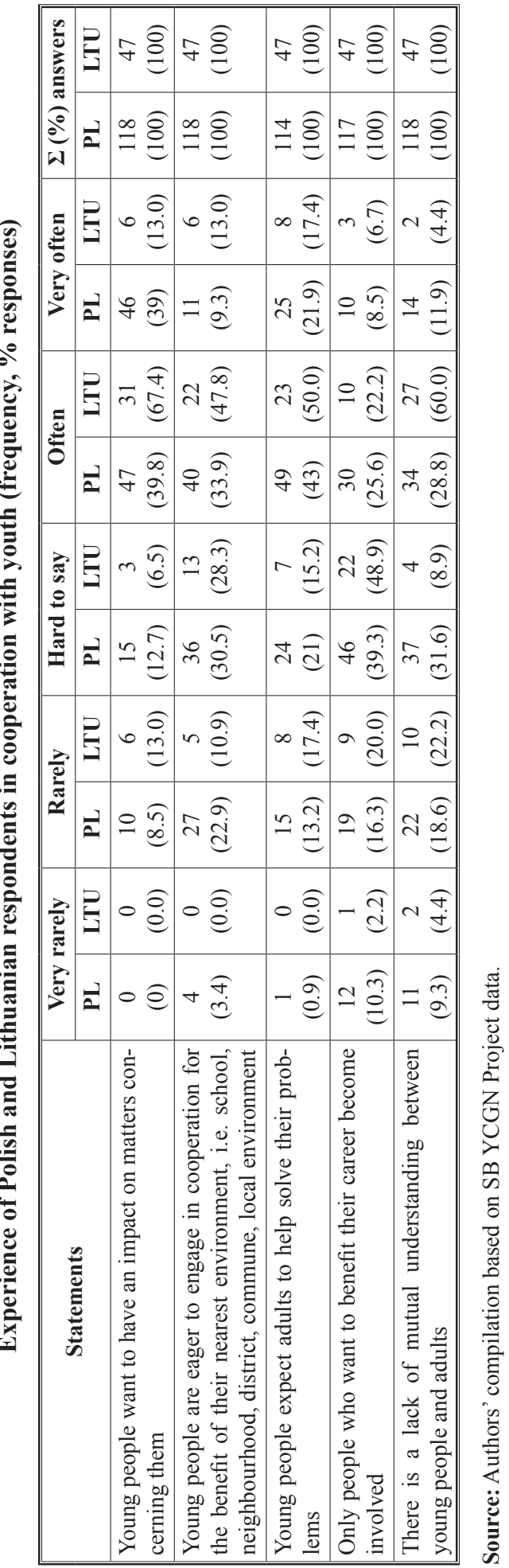


The majority of respondents in both countries could not clearly say whether only people who want to make a career become involved, with Lithuanians choosing $9.6 \mathrm{pp}$ more such answers. The second most common response was "often," selected by 3.4 pp more Polish respondents. Polish and Lithuanian respondents differed in their opinions on the lack of mutual understanding between youth and adults. Most respondents in Poland reported that it was difficult to say, and in Lithuania - that the problem was a frequent one.

The next matter investigated was the level of youth civic engagement in the communes. The survey demonstrated unsatisfactory results in this respect.

A majority of those surveyed in both countries indicated a medium level of engagement; 9.2 pp more in Poland than in Lithuania. The distribution of the variable is shown in Table 4.

Table 4

Assessment of the level of youth civic participation in communes as viewed by Polish and Lithuanian respondents (frequency, \% responses)

\begin{tabular}{|l|c|c|c|c|c|c||}
\hline \multicolumn{1}{|c|}{ Partner } & Very high & High & Medium & Low & Very low & $\begin{array}{c}\Sigma(\%) \\
\text { answers }\end{array}$ \\
\hline 5 Polish communes & $3(2.6)$ & $19(16.7)$ & $59(51.8)$ & $26(22.8)$ & $7(6.1)$ & $114(100)$ \\
\hline Telsiai & $1(2.1)$ & $12(25.5)$ & $20(42.6)$ & $10(21.3)$ & $1(2.1)$ & $47(100)$ \\
\hline \multicolumn{7}{|c|}{ Polish municipalities } \\
\hline Dzierzgoń & 1 & 2 & 6 & 1 & 0 & $10(100) /$ \\
& $(10) /(0.9)$ & $(20) /(1.8)$ & $(60) /(5.3)$ & $(10) /(0.9)$ & $(0) /(0)$ & $114(100)$ \\
\hline Elbląg & 1 & 6 & 13 & 9 & 1 & $30(100) /$ \\
& $(3.3) /(0.9)$ & $(20) /(5.3)$ & $(43.3) /(11.4)$ & $(30) /(7.9)$ & $(3.3) /(0.9)$ & $114(100)$ \\
\hline Gdynia & 1 & 3 & 25 & 11 & 5 & $45(100) /$ \\
& $(2.2) /(0.9)$ & $(6.7) /(2.6)$ & $(55.6) /(21.9)$ & $(24.4) /(9.6)$ & $(11.1) /(4.4)$ & $114(100)$ \\
\hline Iława & $0(0) /(0)$ & 2 & 6 & 2 & 0 & $10(100) /$ \\
& \multicolumn{7}{|c|}{$(20) /(1.8)$} & $(60) /(5.3)$ & $(20) /(1.8)$ & $(0) /(0)$ & $114(100)$ \\
\hline Nowe Miasto Lubawskie & 0 & 6 & 9 & 3 & 1 & $19(100) /$ \\
& $(0) /(0)$ & $(31.6) /(5.3)$ & $(47.4) /(7.9)$ & $(15.8) /(2.6)$ & $(5.3) /(0.9)$ & $114(100)$ \\
\hline
\end{tabular}

Source: Authors' compilation based on SB YCGN Project data.

The second most common answers showed differences between Polish and Lithuanian respondents. Youth civic participation in the commune was low according to Poles and high according to Lithuanians. The conclusion that the situation in this respect is better in Lithuania is not so straightforward considering the differences between the Polish communes. The second largest respondent group from Gdynia and Elbląg claimed that youth participation was low but the corresponding group from Nowe Miasto Lubawskie and Dzierzgoń said it was high.

Youth influence on the decisions taken in communes was viewed differently in the two countries. A majority of Polish respondents said that youth had very little impact on decisions in the commune in 5 areas: social assistance, cultural initiatives, public transport, spatial planning, preparation and implementation of international projects. In Lithuania, according to most respondents, young people have very little impact on commune budget allocation and little impact on public transport, education, spatial planning, election of representatives in local authorities and creation of strategic docu- 
ments in the commune. Alignment with the views of the Polish respondents was observed in the areas of public transport and election of youth representatives in the local authorities. Polish youth have a medium influence on decisions concerning education, development of strategic documents, election of their representatives in the local authorities and commune budget distribution. According to the Lithuanian respondents, young people have a medium extent of influence on cultural initiatives, social assistance and the preparation and implementation of international projects. Polish and Lithuanian youth have a large impact only on the election of their representatives in school/university governments. While this points to significant youth participation in the decision-making process in the immediate institutional environment, where they can learn democratic forms of civic participation, one might worry that it applies only to educational institutions. Although the Polish youth have a relatively greater influence on decisions at the commune level, the extent of this influence is small or very small both in Poland and Lithuania. This points to the need for efforts towards increasing young people's participation in decision-making processes in both countries. The distribution of the variable is shown in Table 5.

The unsatisfactory level of youth civic participation Poland and Lithuania is due to numerous barriers. The opinions of a majority of those surveyed in both countries were similar in 6 out of 11 issues: underestimating the knowledge and experience of young people by decision makers (18.2 pp more Lithuanians than Poles chose that answer); young people's doubts that their participation could change anything (selected by $20.6 \mathrm{pp}$ more Lithuanians than Poles); absence of adults able to motivate young people to engage in public matters (indicated by $33.2 \mathrm{pp}$ more Lithuanians than Poles); keeping youth from co-deciding about public affairs ( $8 \mathrm{pp}$ more answers from Lithuanian respondents); lack of clear information on the opportunities for youth engagement in local affairs (stated by $14.7 \mathrm{pp}$ more Lithuanians than Poles) and young people's lack of interest in local life (indicated by $21.4 \mathrm{pp}$ more Lithuanian respondents). Issues such as disregarding the voice of young people in the decision-making process, failure to involve them in public affairs and lack of clear information about the opportunities for youth participation in local affairs constitute a greater obstacle in Poland, since the majority of Polish respondents rated the impact of these factors as very large while most Lithuanians described it as large. Banning young people from engagement in local affairs by those in charge of them has a moderate impact according to the majority of Lithuanian respondents but a low impact according to the Poles. The distribution of the variable is shown in Table 6.

A majority of Polish and Lithuanian respondents suggested finding a good leader to motivate and engage young people and a greater openness of decision-makers to allow young people's participation in public affairs as the steps necessary to increase youth civic participation. Both options were more frequently selected by Poles than Lithuanians, which suggests a greater severity of that problem in Poland. The respondents from both countries indicated that it was rather necessary to cooperate with institutions implementing youth policies, also within the Baltic Sea region, improve the competence of staff who work with young people and increase the funds for integrating youth in decision-making concerning public affairs. These needs were indicated more often by Lithuanian respondents. The distribution of the variable is shown in Table 7. 


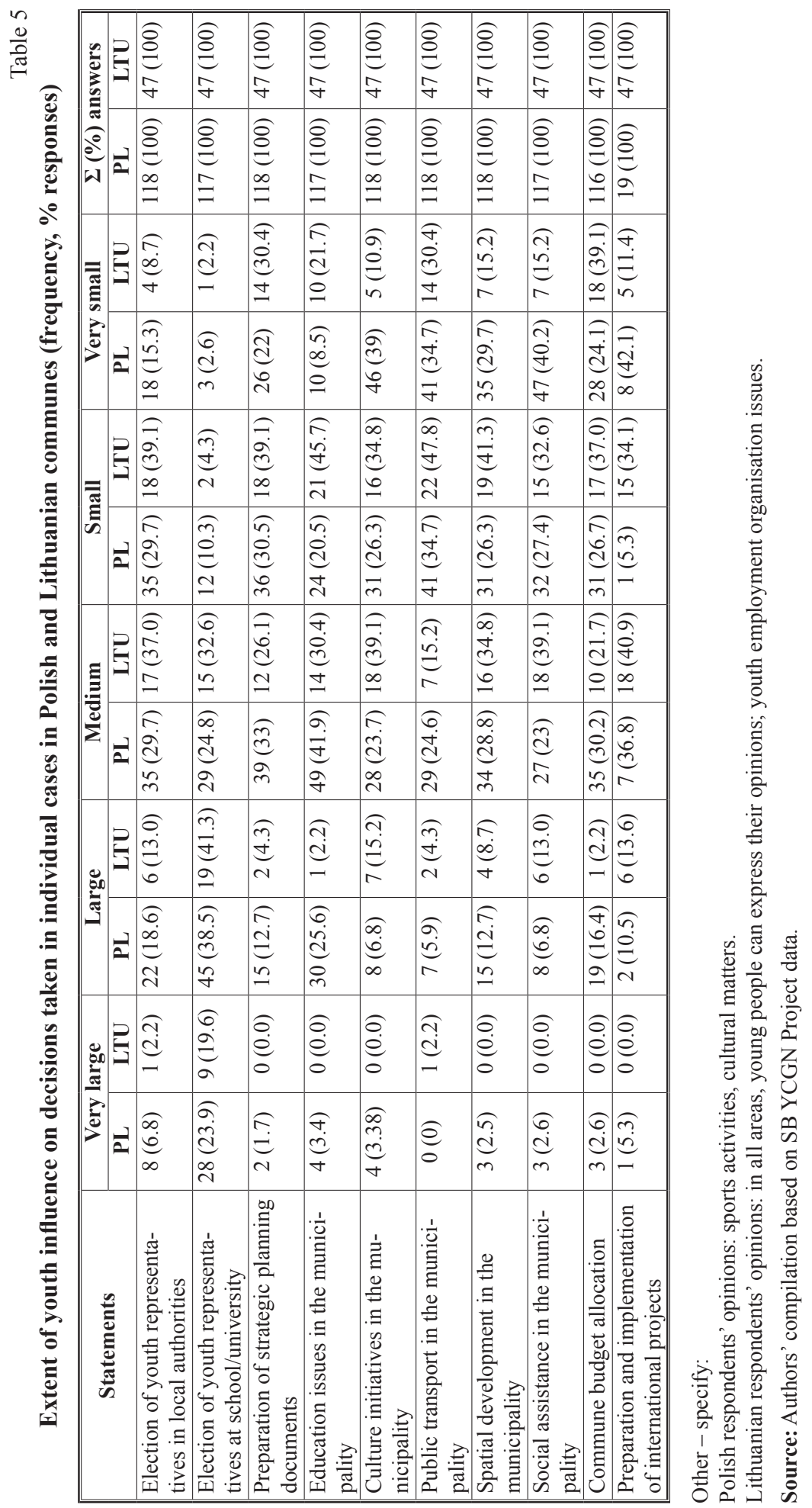


$\frac{0}{2}$

\begin{tabular}{|c|c|c|c|c|c|c|c|c|c|c|c|c|c|}
\hline 离 & 2 & fᄋ & 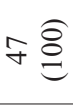 & 于े & 于 & 于气 & 于 & f气 & f于 & f & F。 & 于 & $\frac{.0}{0.0}$ \\
\hline$\underbrace{\varrho}_{\omega}$ & $\bar{a}$ & 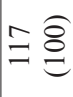 & 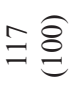 & 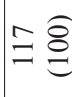 & $\cong 气$ & $\cong 气$ & $\Xi 气$ & $\stackrel{\varrho}{=}$ & $\stackrel{\varrho}{=}$ & $\triangleq \bigodot$ & $\cong 气$ & $\because \underset{8}{\Xi}$ & \\
\hline 递 & 2 & $-\underset{\overbrace{}}{\overparen{\overbrace{}}}$ & $-\stackrel{\overparen{\sim}}{\stackrel{n}{\natural}}$ & $m \underset{\theta}{\overparen{\theta}}$ & $+\underset{\infty}{\stackrel{E}{\infty}}$ & $n \stackrel{\widehat{g}}{\stackrel{0}{g}}$ & $0 \stackrel{\stackrel{\partial}{g}}{\stackrel{g}{V}}$ & $\infty \stackrel{\overparen{f}}{\stackrel{f}{\Xi}}$ & 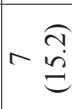 & $a \stackrel{6}{\stackrel{0}{=}}$ & $\pm \underset{\overbrace{}}{\stackrel{\sigma}{0}}$ & $=\begin{array}{l}\sigma \\
\dot{d}\end{array}$ & : \\
\hline 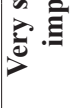 & $\vec{a}$ & $\curvearrowright \underset{尺}{\Xi}$ & 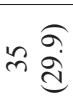 & $\infty \underset{\ominus}{\infty}$ & {$\left[\begin{array}{cc}0 & \tilde{n} \\
0 & \vdots\end{array}\right.$} & 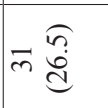 & $\begin{array}{ll}\sigma \\
0 & \vdots \\
& d\end{array}$ & 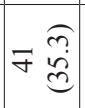 & $\mathbb{H}^{\infty} \underset{\infty}{\infty}$ & নิ & f) & 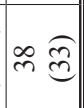 & \\
\hline & ?. & 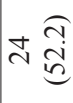 & 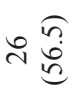 & $\approx \underset{7}{\stackrel{a}{a}}$ & 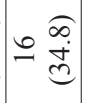 & $=\frac{\hat{m}}{\dot{E}}$ & $2 \frac{\widehat{?}}{\dot{y}}$ & $\infty \underset{\stackrel{0}{0}}{-}$ & 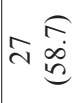 & 잉 & $\bar{\sim} \underset{\stackrel{\theta}{g}}{\stackrel{\theta}{ \pm}}$ & 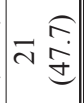 & \\
\hline 菩 & $\bar{a}$ & ల) & 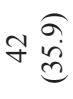 & ల & 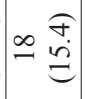 & $\infty \underset{\sim}{\stackrel{\sigma}{d}}$ & ले & $\hat{m} \frac{\widehat{a}}{\stackrel{c}{c}}$ & fr & F & 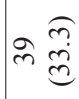 & $\infty \begin{array}{c}\infty \\
\infty\end{array}$ & 0 \\
\hline$\stackrel{\stackrel{!}{\Xi}}{\Xi}$ & $?$ & 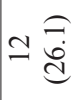 & $=\stackrel{\widehat{a}}{\mathfrak{d}}$ & $\begin{array}{rr}0 & 0 \\
0 & 0 \\
0 & 0\end{array}$ & 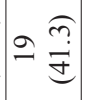 & $\because \underset{0}{\stackrel{0}{i}}$ & $\pm \underset{\mathscr{f}}{\stackrel{f}{0}}$ & $\because \underset{0}{\stackrel{\infty}{\dot{d}}}$ & $\infty \stackrel{\overbrace{}}{\stackrel{\Im}{\Xi}}$ & $+\underset{\infty}{\stackrel{\sigma}{\infty}}$ & $\infty \stackrel{\overparen{f}}{\stackrel{\overbrace{}}{\Xi}}$ & 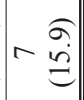 & \\
\hline$\sum^{E}$ & $\bar{a}$ & $\approx \widehat{\hat{a}}$ & $\widehat{\imath} \widehat{\overbrace{}}$ & 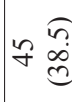 & $\approx \stackrel{\substack{\infty \\
\infty}}{=}$ & $\approx \frac{6}{0}$ & $\begin{array}{cc}\widetilde{n} \\
\dot{d} \\
\end{array}$ & 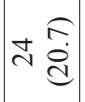 & $\approx \stackrel{\infty}{\stackrel{\infty}{\rightleftharpoons}}$ & 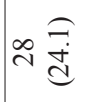 & 요 & $\begin{array}{lll}\widehat{\imath} & \widehat{\imath} & \mathfrak{d}\end{array}$ & \\
\hline $\begin{array}{l}\overline{\tilde{E}} \\
\stackrel{\Xi}{\Xi} \\
\end{array}$ & 2 & $\sim \underset{\overbrace{}}{\stackrel{\overbrace{}}{+}}$ & $-\stackrel{\overparen{d}}{\mathrm{~d}}$ & $\sim \underset{Ð}{\stackrel{f}{+}}$ & $+\underset{\infty}{\overparen{\infty}}$ & $0 \stackrel{\stackrel{\sigma}{g}}{=}$ & 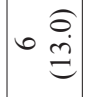 & $\sim \underset{\overbrace{}}{\stackrel{\overbrace{}}{ \pm}}$ & $\sim \stackrel{\overbrace{}}{\underset{+}{+}}$ & $0 \stackrel{0}{0}$ & 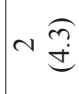 & 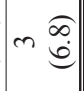 & \\
\hline ב⿱ & $\vec{a}$ & $\therefore \stackrel{\infty}{\infty}=$ & $\simeq \stackrel{\overbrace ?}{0}$ & $\approx \widehat{\vartheta} \stackrel{\theta}{g}$ & $F \widetilde{\approx}$ & $\because \underset{\mathfrak{g}}{\stackrel{\overbrace{}}{\varrho}}$ & $=\stackrel{\widehat{\vartheta}}{\stackrel{\theta}{a}}$ & $=\tilde{\tilde{n}}$ & $=\frac{\tilde{n}}{a}$ & 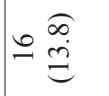 & $\infty \underset{\substack{\infty \\
\dot{\theta}}}{ }$ & $\infty E$ & 3 \\
\hline 莕 & ?ביב⿱二厶) & $-\stackrel{\overparen{d}}{\mathrm{~d}}$ & $-\stackrel{\overparen{d}}{\mathrm{~d}}$ & - กิ & m $\stackrel{\tilde{n}}{\tilde{g}}$ & $-\stackrel{\overparen{d}}{d}$ & $-\stackrel{\widetilde{d}}{\mathbb{d}}$ & 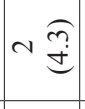 & N & $-\stackrel{\overparen{d}}{\mathrm{~d}}$ & $-\overparen{\overparen{d}}$ & $\sim \stackrel{\overparen{n}}{\underset{+}{+}}$ & c \\
\hline & a & 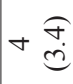 & $-\stackrel{\hat{g}}{e}$ & $n \stackrel{?}{ \pm}$ & 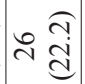 & $n \stackrel{\overparen{?}}{ \pm}$ & 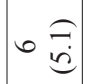 & $m \stackrel{\substack{0 \\
d}}{|c|}$ & $-\widehat{\hat{a}}$ & $-\frac{\hat{g}}{\hat{e}}$ & 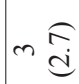 & $\sim \stackrel{\overparen{\vartheta}}{=}$ & 菢 \\
\hline 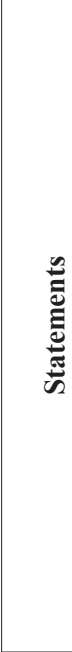 & & 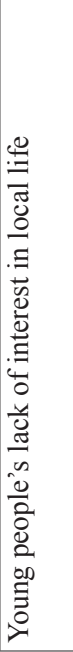 & 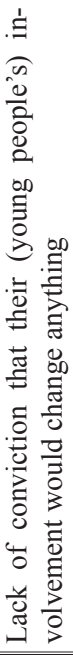 & 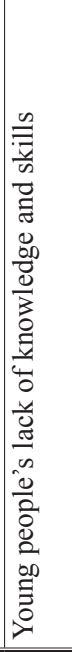 & 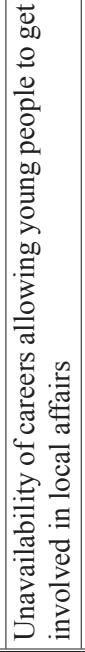 & 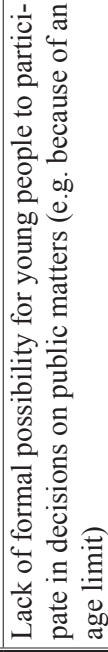 & 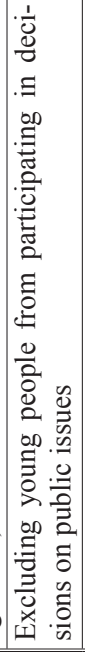 & 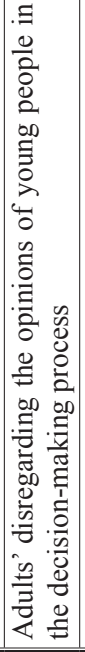 & 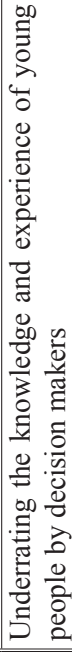 & 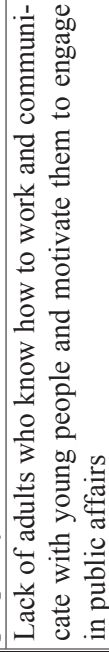 & 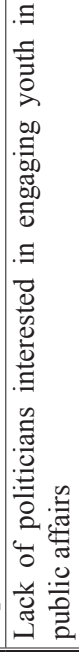 & 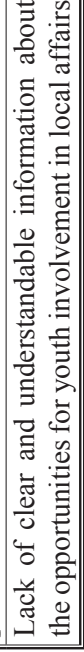 & 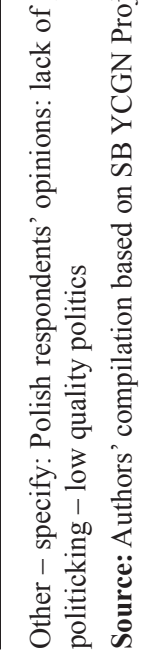 \\
\hline
\end{tabular}


PP 4 '19 Youth civic participation from the perspective of Polish...

65

\begin{tabular}{|c|c|c|c|c|c|c|c|c|c|}
\hline \multirow{2}{*}{\multicolumn{2}{|c|}{ 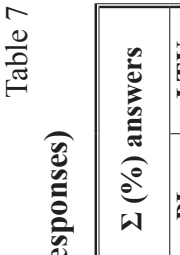 }} & 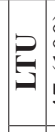 & 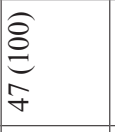 & $\begin{array}{l}\stackrel{\partial}{\ominus} \\
\text { f }\end{array}$ & 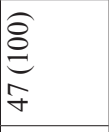 & 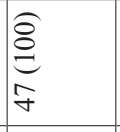 & 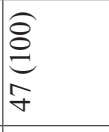 & $\begin{array}{l}\underset{8}{\varrho} \\
\text { f }\end{array}$ & \multirow{13}{*}{ 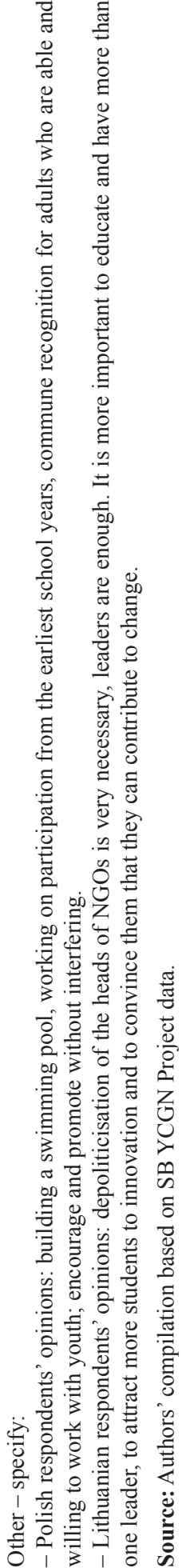 } \\
\hline & & a & $\begin{array}{l}\stackrel{\ominus}{\varrho} \\
ٍ \\
= \\
=\end{array}$ & 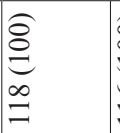 & $\begin{array}{l}\underset{8}{\varrho} \\
ٍ \\
0 \\
=\end{array}$ & $\begin{array}{l}\underset{8}{\varrho} \\
ٍ \\
=\end{array}$ & $\begin{array}{l}\stackrel{\Xi}{\varrho} \\
\triangleq \\
\Xi\end{array}$ & $\begin{array}{l}\stackrel{\varrho}{\varrho} \\
ٍ\end{array}$ & \\
\hline $\begin{array}{l}0 \\
\text { है } \\
\overline{0}\end{array}$ & 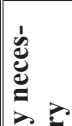 & ?בְ & 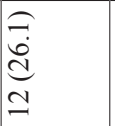 & $\begin{array}{l}\sigma \\
\stackrel{6}{a} \\
a \\
a\end{array}$ & 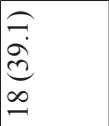 & 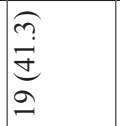 & $\begin{array}{l}\hat{I} \\
\text { ḋ } \\
\text { d. }\end{array}$ & $\begin{array}{l}\partial \\
\dot{0} \\
\ddot{n} \\
\tilde{n}\end{array}$ & \\
\hline 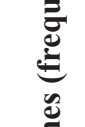 & 焉 & $\vec{a}$ & 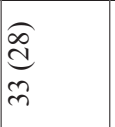 & 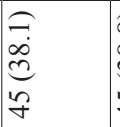 & $\begin{array}{l}\sigma \\
\infty \\
\infty \\
0 \\
0 \\
\ddots \\
f\end{array}$ & 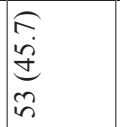 & 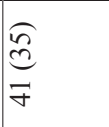 & $\begin{array}{l}\hat{8} \\
\text { है }\end{array}$ & \\
\hline $\begin{array}{l}\bar{\Xi} \\
\text { Ë }\end{array}$ & 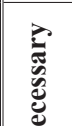 & 곤 & 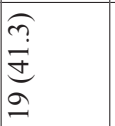 & 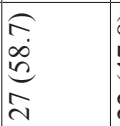 & 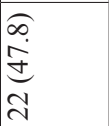 & 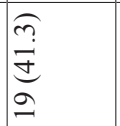 & 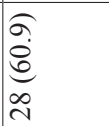 & 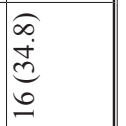 & \\
\hline & 离 & $\vec{a}$ & 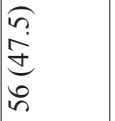 & 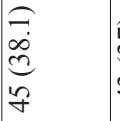 & $\begin{array}{l}\underset{\hat{\sigma}}{0} \\
\mathfrak{g}\end{array}$ & 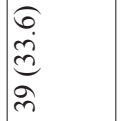 & 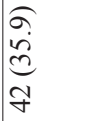 & 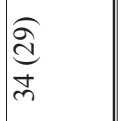 & \\
\hline 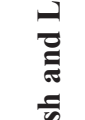 & 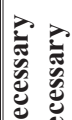 & ב⿱ & 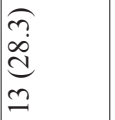 & $\begin{array}{l}\sigma \\
\stackrel{0}{2} \\
\stackrel{2}{a} \\
a\end{array}$ & 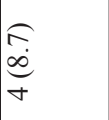 & 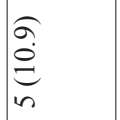 & 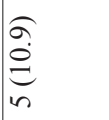 & $\underset{\hat{\sigma}}{\hat{\infty}}$ & \\
\hline 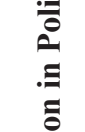 & 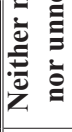 & a & $\begin{array}{l}\underset{f}{J} \\
\stackrel{\Xi}{\Xi} \\
\beth\end{array}$ & 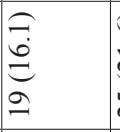 & 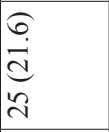 & 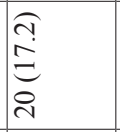 & 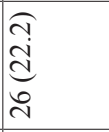 & $\begin{array}{l}\infty \\
0 \\
e \\
\infty \\
\infty\end{array}$ & \\
\hline 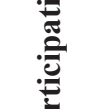 & 递 & 2 & $\underset{\sim}{\stackrel{N}{ \pm}}$ & $\underset{\substack{d \\
-}}{d}$ & 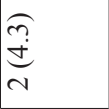 & 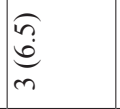 & 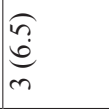 & 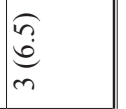 & \\
\hline . & 离 & a & 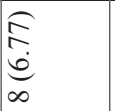 & $\sqrt{\tilde{0}}$ & $\underset{\sim}{\stackrel{F}{\rightleftharpoons}}$ & $\begin{array}{l}\sigma \\
\stackrel{6}{d} \\
m\end{array}$ & 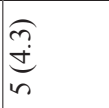 & $\begin{array}{c}\sigma \\
\underset{m}{d} \\
m\end{array}$ & \\
\hline $\begin{array}{l}\bar{E} \\
\bar{E} \\
0\end{array}$ & 离 & 2 & 官 & $\frac{\partial}{0}$ & 富 & 㝘 & ô & $\stackrel{0}{\hat{\theta}}$ & \\
\hline . & (ُ) & 글 & $\begin{array}{l}2 \\
\infty \\
\infty \\
\infty \\
\ddots \\
\forall\end{array}$ & $\underset{\substack{n \\
d \\
m}}{a}$ & $\stackrel{\hat{\partial}}{\hat{e}}$ & $\underline{\hat{a}}$ & $\begin{array}{c}\sigma \\
d \\
d \\
m\end{array}$ & $\begin{array}{c}\sigma \\
i \\
\text { id } \\
m\end{array}$ & \\
\hline 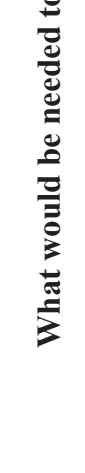 & 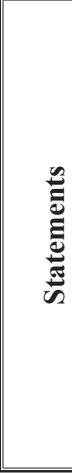 & & 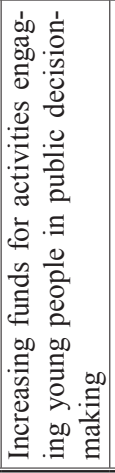 & 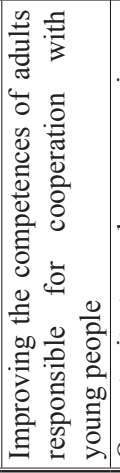 & 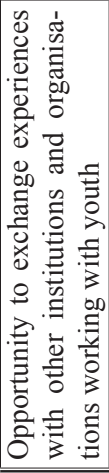 & 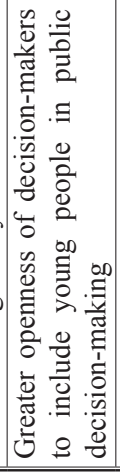 & 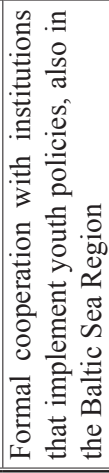 & 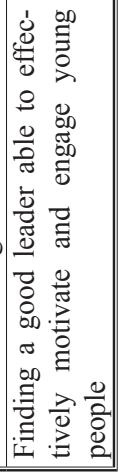 & \\
\hline
\end{tabular}


As to the evaluation of different forms of increasing youth civic participation, a majority of Polish and Lithuanian respondents expressed similar opinions in 12 out of 16 matters investigated. According to the respondents, youth civic participation can be increased through youth meetings with representatives of NGOs (with Poles choosing this answer 2.8 pp more often than Lithuanians), the opportunity to comment on draft decisions of local authorities (selected $10.8 \mathrm{pp}$ more frequently by Lithuanian respondents), creating youth councils in communes (indicated $13.7 \mathrm{pp}$ more frequently by Lithuanians) and informing in the media about the opportunities for youth civic participation (15.8 pp more answers given by Lithuanians). Lithuanians also more frequently (by 11,5 pp) expressed their preference for youth cooperation network development at local level. Lithuanian respondents were also more inclined to indicate options such as allowing youth to comment on draft decisions of school authorities (by 16.7 pp), creating a list of areas where young people can co-decide (by $10.4 \mathrm{pp}$ ) and allowing youth to co-decide on the allocation of commune budgets (by $20.3 \mathrm{pp}$ ). In the opinion of most respondents, holding public hearings for youth and cooperation in networks at cross-border level are also effective. Both these options were more often selected by Lithuanians - by 10.7 and 15.9 pp, respectively. As to "round tables" organised by public institutions as a form of dialogue between public office staff, politicians and young people, Lithuanians were more likely to find them effective in increasing youth participation (by $4.1 \mathrm{pp}$ ). The distribution of the variable is shown in Table 8 .

According to most Polish and Lithuanian respondents, meetings of officials with young people in schools/universities and in public institutions are moderately effective. Lithuanians selected these answers more often than Poles (by 13.5 and $15.4 \mathrm{pp}$, respectively). Polish and Lithuanian respondents had different views on the effectiveness of three of the options. In the opinion of most of the Lithuanian respondents, promotion of youth civic participation via the Internet and by the youth leaders is an effective method, but most of the Poles surveyed found it highly effective. Politicians' meetings with young people were considered effective by a majority of Poles but moderately effective by most of the Lithuanians.

A majority of those surveyed from both countries believed that the capacity of institutions to engage young people in the commune life could be increased through knowledge or skills improvement. The majority of Polish respondents pointed to the need for more knowledge - sociological first, followed by psychological and pedagogical, whereas their Lithuanian counterparts were most likely to choose psychological knowledge, followed by sociological and pedagogical. Political science, including the issues of civic education and NGOs, is also an important area of knowledge that should be improved in both countries. In addition, the Polish respondents stressed the need for better knowledge of economics, law and sport. These findings demonstrate that the representatives of institutions are aware of the need for continual competence development.

\section{Summary}

Project SB YCGN supports EU efforts by delivering knowledge on youth civic participation and implementation of practical steps to help develop the dialogue between the institutional environment and young people in various forms, e.g. in the decision-making processes and cross-border cooperation. 
$\frac{0}{0}$

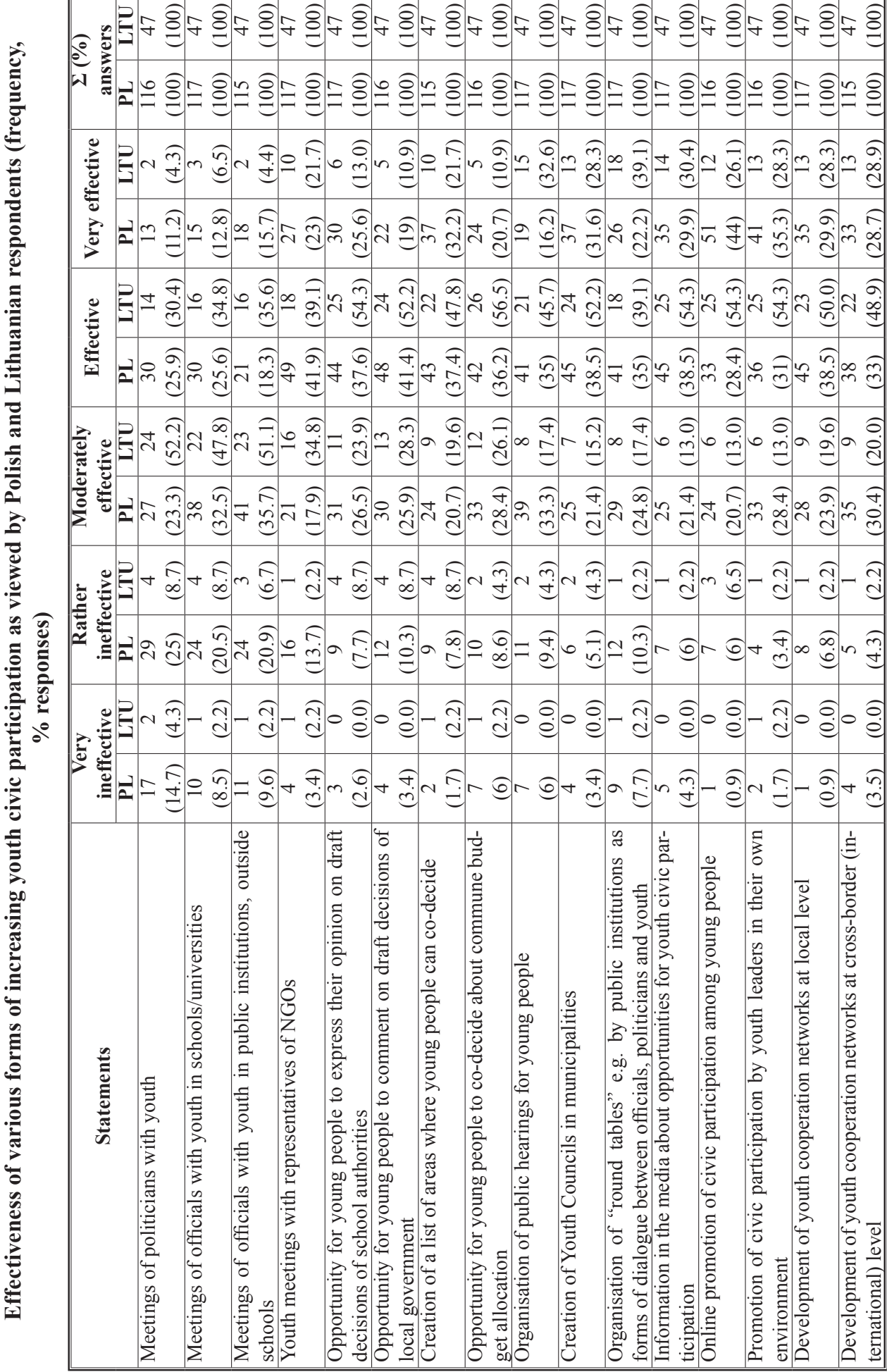


A survey conducted in five Polish and one Lithuanian commune in the framework of project SB YCGN showed that, according to most respondents from both countries, youth civic participation is currently at a medium level. On this basis the authors verified the research hypothesis that similar levels of youth civic participation, barriers, needs and methods of operation in the Polish and Lithuanian communes investigated determine the need to tighten cross-border cooperation in the Baltic Sea region.

As to the attitudes of young people to engaging in the affairs of their immediate environment, it should be emphasised that youth want to have an influence on matters that concern them. A greater share of Lithuanians than Poles stated that young people are often willing to engage in cooperation for the benefit of their immediate environment. This shows that there is potential for the development of cooperation between adults and young people in shaping the local social life.

However, young people in both countries have a very limited impact on the decisions taken by commune authorities. A majority of Polish respondents pointed to the very low extent of influence exercised by young people in 5 areas: social assistance, cultural initiatives, public transport, spatial planning and preparation and implementation of international projects. In Lithuania this problem was less serious because it only applied to the commune budget allocation. According to a majority of Lithuanian respondents, young people have a limited influence on matters concerning public transport, education, spatial planning, election of their representatives to local authorities and creation of strategic documents in the commune. Polish youth have a medium influence on the decisions taken by commune authorities concerning education, development of strategic documents, election of their representatives to the local authorities and commune budget distribution. In the opinion of most Lithuanian respondents, young people have a medium extent of influence on cultural initiatives, social assistance and preparation and implementation of international projects. The survey revealed that young people in both countries have a large or very large impact only on the election of their representatives at school/university.

It is crucial to overcome the barriers to cooperation with young people in Polish and Lithuanian communes. The Polish and Lithuanian respondents identified similar barriers to youth civic participation: underestimation of the knowledge and experience of young people by decision makers, young people's doubts that their participation could change anything, shortage of adults who know how to work with young people and motivate them to engage in public affairs; keeping youth from co-deciding on public affairs; lack of clear information on the opportunities for young people to engage in local affairs and their lack of interest in local life. The greatest limitations in Poland (more serious than in Lithuania) are as follows: ignoring the opinions of young people in the decision-making process, politicians' reluctance to involve young people in public matters and lack of clear information on the opportunities for youth participation. Most of the Lithuanian respondents identified the following major barriers: young people's lack of knowledge and skills, as well as absence of formal opportunity to participate in the decision-making process concerning public affairs.

In the opinion of most of the Polish and Lithuanian respondents, these obstacles can be eliminated by finding a good leader to motivate and engage young people and greater openness of decision-makers to allow youth to co-decide on public affairs. The steps 
considered necessary by most respondents from both countries (more in Lithuania than in Poland) included formal cooperation with institutions implementing youth policies in the Baltic Sea region, increasing the funds for integrating youth in decision-making concerning public affairs and improving the competences of staff responsible for cooperation with young people. The need for knowledge improvement was stressed: sociology, psychology and pedagogy was indicated by Polish respondents, while Lithuanians opted for more psychological training. Another important area of knowledge in both countries is political science and in Poland, additionally, economics and law.

Similar views were expressed by those surveyed from both countries as to the effectiveness of the different forms of increasing youth civic participation. They considered the following efforts to be effective: creating opportunities to comment on draft decisions of local authorities, creating youth councils in communes, informing of youth civic participation opportunities in the media, development of youth cooperation networks at local level, allowing youth to comment on draft decisions of school authorities, listing the areas in which young people can co-decide, allowing youth to participate in decisions on commune budget allocation, organisation of public hearings for young people, and "round tables" as a form of dialogue between officials, politicians and young people. These options were more often indicated by Lithuanian respondents, whereas most of the Poles surveyed considered youth meetings with NGO representatives to be highly effective.

The results of the quantitative studies carried out as part of project SB YCGN revealed a gap between the current and desired level of youth civic participation at local level. This determines the need to intensify the efforts of various entities at local, national and international level with the aim to increase youth civic participation. In this context, one may highlight the importance of project SB YCGN activities, which addresses the identified problems and expectations to a significant extent. It promotes cooperation between entities dealing with the issues of civic participation within the Baltic Sea region countries, provides facts on the state and opportunities for the development of such cooperation, supports the institutionalised environment of decision makers and young people, while encouraging dialogue, inclusivity of decision-making processes and cross-border cooperation.

\section{Bibliography}

Brodie E., Cowling E., Nissen N., et al. (2009), Understanding participation: a literature review, Pathways through Participation, https://partycypacjaobywatelska.pl/wp-content/uploads/2015/08/ understanding_participation.pdf, 15.06.2019.

Chodubski A. (2014), Młodzież jako przedmiot i podmiot życia publicznego, in: Polityka Młodzieżowa Unii Europejskiej, eds. M. Boryń, B. Duraj, S. Mrozowska, Wydawnictwo Adam Marszałek, Toruń.

Długosz D., Wygnański J. J. (2005), Obywatele współdecydują. Przewodnik po partycypacji społecz$n e j$, Stowarzyszenie na rzecz Forum Inicjatyw Pozarządowych, Warszawa.

EU Youth Strategy 2010-2018, https://ec.europa.eu/youth/policy/youth-strategy/strategy-2010-2018_ en, 11.16.2019.

Gąsior-Niemiec A. (2014), Problematyka młodzieży w perspektywie europejskiej i krajowej, in: Polityka młodzieżowa wymiar krajowy i europejski, eds. A. Gąsior-Niemiec, A. Kołomycew, B. Kotarba, Wydawnictwo Uniwersytet Rzeszowski, Rzeszów. 
Maciaszek P. (2016), Partycypacja społeczna młodzieży na przykładzie młodzieżowych rad gmin - część II, „Rocznik Samorządowy”, vol. 5.

Markiewicz M. (1964), Wspótczesna młodzież jako przedmiot badań naukowych, Wydawnictwo UAM, Poznań.

Napiontek O. (2013), Szkoła - przestrzeń obywatelskiego uczestnictwa, in: Edukacja obywatelska $w$ działaniu, eds. A. Kordasiewicz, P. Sadura, Wydawnictwo Naukowe Scholar, Warszawa.

Partycypacja organizacji pozarzadowych w procesie stanowienia prawa w latach 2014-2017, http:// www.partycypacjango.kolping.pl/czytelnia.html, 10.06.2019.

Partycypacja obywatelska Młodzieży. Przykład Młodzieżowych Rad Gmin (2015), Fundacja Civis Polonus, Warszawa.

Pater M., Pater W. (2008), Polityka młodzieżowa Unii Europejskiej, UKIE CIE, Warszawa.

Pawliczuk W. (2000), The definitions of the term “youth”. A review of conceptions, „Postępy Nauk Medycznych", no. 6.

Rizzini I., Torres M. A., Del Rio N. A. L. (2009), Youth And Civic Engagement In The Americas Preliminary Findings From A Three-City Study: Rio De Janeiro, Chicago, And Mexico City, https:// www.uam.mx/cdi/pdf/p_investigacion/kellogg.pdf, 10.06.2019.

Rystina I., Kussainova Z. (2014), Comparative Analysis of National Youth Policy in Different Countries, "Procedia - Social and Behavioral Sciences", no. 140.

Sokalska E. (2016), Znaczenie konsultacji społecznych w demokracji partycypacyjnej, „Opolskie Studia Administracyjno-Prawne", vol. 14.

Teney C., Hanquinet L. (2012), High Political Participation, High Social Capital? A relational analysis of youth social capital and political participation, "Social Science Research", vol. 41, no. 5.

Youth in Action 2007-2013, http://www.sep.gov.mk/en/content/?id=201\#.XOUwNsgzaUk, 10.06.2019.

\section{Partycypacja obywatelska młodzieży z perspektywy polskich i litewskich instytucji na przykładzie projektu South Baltic Youth Core Group Network}

\section{Streszczenie}

Celem artykułu było ukazanie partycypacji obywatelskiej młodzieży w opinii pracowników instytucji działających na terenie 5 polskich gmin: Dzierzgoń, Elbląg, Gdynia, Iława i Nowe Miasto Lubawskie i litewskiej gminy Teslai. W ramach projektu SB YCGN przeprowadzono badanie metodą sondażu diagnostycznego z wykorzystaniem techniki ankiety internetowej na 118 respondentach z 53 polskich instytucji i 47 respondentach z 10 litewskich instytucji. Na podstawie wyników badań ilościowych potwierdzono hipotezę: podobieństwa w zakresie poziomu partycypacji obywatelskiej młodzieży, barier, potrzeb i efektywnych metod działania w badanych gminach z Polski i Litwy determinują potrzebę zacieśniania współpracy transgranicznej.

Słowa kluczowe: młodzież, partycypacja obywatelska, Polska, Litwa, SB YCGN projekt 